\title{
Fatty acid induced insulin resistance in rat-1 fibroblasts overexpressing human insulin receptors: impaired insulin- stimulated mitogen-activated protein kinase activity
}

\author{
I. U sui, Y. Takata, T. I mamura, H . M orioka, T. Sasaoka, T. Sawa, H . I shihara, M . Ishiki, M . Kobayashi
}

The First Department of Medicine, Toyama Medical and Pharmaceutical University, Sugitani, Toyama, Japan

Summary Saturated fatty acids cause insulin resistance but the underlying molecular mechanism is still unknown. We examined the effect of saturated nonesterified fatty acids on insulin binding and action in transfected Rat-1 fibroblasts, which over-expressed human insulin receptors. Incubation with $1.0 \mathrm{mmol} / \mathrm{l}$ palmitate for 1-4 h did not affect insulin binding, insulin receptor autophosphorylation, insulin-stimulated tyrosine kinase activity toward poly $\left(\mathrm{Glu}^{4}: \mathrm{Tyr}^{1}\right)$, pp185 and Shc phosphorylation and PI3-kinase activity in these cells. However, the dose response curve of insulin-stimulated glucose transport was right-shifted. Palmitate inhibited the maximally insulin-stimulated mitogen activated protein (MAP) kinase activity toward synthetic peptide to $7 \%$ that of control. The palmitate treatment influenced neither cytosolic protein kinase A activity nor cAMP levels. These results suggested that 1) palmitate did not inhibit the early steps of insulin action from insulin binding to pp185 or Shc phosphorylation but inhibited insulinstimulated MAP kinase, and that 2) palmitate decreased insulin sensitivity as manifested by inhibited insulin-stimulated glucose uptake. In conclusion, the mechanism of saturated non-esterified fatty acid induced insulin resistance in glucose uptake may reside at post PI3-kinase or Shc steps, including the level of MAP kinase activation. [Diabetologia (1997) 40: 894-901]

Keywords Non-esterified fatty acid, insulin resistance, MAP kinase, insulin receptor, glucose transport.
Received: 15 January 1997 and in revised form: 9 April 1997

Corresponding author: Y. Takata M.D., The First Department of Medicine, Toyama Medical and Pharmaceutical University, Sugitani, Toyama 930-01, Japan

A bbreviations: NEFA, Non-esterified fatty acid; pp185, 185 $\mathrm{kDa}$ phosphoprotein; IRS-1/2, insulin receptor substrate 1/2; Shc, Src homologous and collagen protein; PI3-kinase, phosphatidyl inositol 3-kinase; MAP kinase, mitogen-activated protein kinase; cAMP, adenosine $3^{\prime}: 5$ '-cyclic monophosphate; PKA, protein kinase A; NIDDM, non-insulin-dependent diabetes mellitus; ERK, extracellular signal-regulated kinase; MEK, mitogen/ERK kinase; HEPES, 2-[4-(2-Hydroxyethyl)1-piperazinyl]ethanesulphonic acid; PMSF, phenylmethylsulphonyl fluoride; SDS-PAGE, sodium dodecyl sulphate polyacrylamide gel electrophoresis; EGF, epidermal growth factor, TNF- $\alpha$; tumor necrosis factor- $\alpha$; PtdIns, phosphatidyl inositol; BSA, bovine serum albumin; KRP, Krebs Ringer phosphate; DMEM, Dulbecco's modified Eagle's medium; PBS, phosphate buffered saline; DTT, dithiothreitol.
Insulin resistance in obesity and non-insulin-dependent diabetes mellitus (NIDDM) is often associated with hyperlipidaemia, especially an increased level of non-esterified fatty acids (NEFA) [1]. Furthermore, the infusion of NEFA caused insulin resistance even in healthy subjects [2, 3]. Therefore, NEFA seems to play an important role in insulin resistance in patients with obesity and NIDDM. To clarify the role of NEFA in glucose and fat metabolism, several studies have been conducted in animal models of obesity and NIDDM, such as ob/ob mice and KKAy mice [4-6]. In these models, high NEFA levels in the serum were associated with the impairment of insulin receptor function, such as insulin binding and insulin receptor tyrosine kinase. Accordingly, the abnormalities in the insulin receptor function were ameliorated with the reduction of the serum NEFA level by treating the animals with a hypoglycaemic agent or insulin sensitizer [5, 7]. However, the improved insulin 
receptor function may be secondary to glycaemic control in these studies. When adipocytes were treated with NEFA, insulin-stimulated glucose uptake was impaired $[8,9]$. Decreased insulin receptor binding affinity was thought to be the primary cause for these phenomena. However, the effect of NEFA on insulin binding was varied among different cells and the various types of NEFA employed caused different results [8-12]. Furthermore, the effect of NEFA on post-receptor insulin-mediated signalling is still poorly understood and there is no conclusive data to explain the mechanism how NEFA inhibits insulin action.

IRS-1/IRS-2 molecules (pp185), upon phosphorylation by insulin receptor tyrosine kinase, form a complex with several other signalling molecules including phosphatidyl inositol (PI)-3 kinase, which is important for the translocation of glucose transporters [13]. Shc after being phosphorylated by insulin receptor tyrosine kinase leads to the activation of ras and mitogen activated protein (MAP) kinase [14], which is important for insulin stimulated mitogenesis and possibly also for metabolic action [15]. To understand the mechanism of NEFA induced insulin resistance, we investigated the effect of NEFA on these signalling molecules in Rat-1 fibroblasts over-expressing human insulin receptors, in which the signalling cascades have been relatively well characterized $[16,17]$.

\section{Materials and methods}

$M$ aterials. Palmitate and fatty acid-free bovine serum albumin (BSA) were purchased from Sigma (St. Louis, Mo., USA). The WAKO non-esterified fatty acid (NEFA) C kit was from WAKO Pure Chemicals (Osaka, Japan). [ $\left.\gamma^{3}{ }^{32} \mathrm{P}\right]-\mathrm{ATP}$ $(\sim 185 \mathrm{TBq} / \mathrm{mmol})$ and $\left[{ }^{125} \mathrm{I}\right]$-insulin $(\sim 74 \mathrm{TBq} / \mathrm{mmol})$ were purchased from Amersham (Arlington Heights, Ill., USA). [Methyl- $\left.{ }^{3} \mathrm{H}\right]$-thymidine $(\sim 3.33 \mathrm{TBq} / \mathrm{mmol})$ and $\left[1,2,-{ }^{3} \mathrm{H}\right]-2-$ deoxy-D-glucose were from New England Nuclear (Boston, Mass., USA). Porcine insulin was kindly provided by the Shimizu Pharmaceutical Co. (Shizuoka, Japan). A monoclonal anti-phosphotyrosine antibody (PY20), polyclonal anti-Shc antibodies and a monoclonal anti-ERK2 (extracellular signal regulated kinase) antibody were purchased from Transduction Laboratories (Lexington, Ky., USA). A polyclonal antiGLUT 1 antibody was kindly provided by Dr. Asano (Tokyo University, Tokyo, Japan). PD98059, a specific mitogen/ERK kinase (MEK) inhibitor, was from New England Biolabs, Inc. (Beverly, Mass., USA). Electrophoresis reagents were from Bio-Rad (Hercules, Calif., USA). All other reagents were from standard suppliers.

Preparation of high NEFA medium. Palmitate is chosen as a representative saturated NEFA because it is a major component of the saturated NEFA in the serum and does not produce free radicals, unlike unsaturated NEFA $[9,18]$. High non-esterified fatty acid medium was prepared by the method described previously [19]. Briefly, $1 \mathrm{mmol}$ palmitate was dissolved in hexane and then $10 \mathrm{~g}$ celite was added. After evaporating hexane under a $\mathrm{N}_{2}$ stream, $25 \mathrm{~g}$ palmitate-coated celite particles were incubated in 1 liter of Krebs Ringer phosphate (KRP)-HEPES buffer, $\mathrm{pH} 7.4$ containing (in mmol/l) 131 $\mathrm{NaCl}, 4.7 \mathrm{KCl}, 2.5 \mathrm{CaCl}_{2}, 1.2 \mathrm{MgSO}_{4}, 2.5 \mathrm{NaH}_{2} \mathrm{PO}_{4}, 10 \mathrm{HE}-$ PES, and $1 \%$ fatty acid free-BSA for more than $30 \mathrm{~min}$ at room temperature. The particles were removed by centrifugation at $4{ }^{\circ} \mathrm{C}$ for $10 \mathrm{~min}$ at $15000 \times \mathrm{g}$ and filtration through the filter with pore size of $0.25 \mu \mathrm{m}$. After adjusting the $\mathrm{pH}$ to 7.4 and the concentration of palmitate to $1 \mathrm{mmol} / \mathrm{l}$, the medium was stored at $4{ }^{\circ} \mathrm{C}$ until it was used for the experiment. For the control study, KRP-HEPES buffer containing $1 \%$ BSA without palmitate was prepared by the same method.

Cell culture. Rat-1 fibroblasts over-expressing wild-type human insulin receptors (HIRc-B cells) were kindly provided by Dr. J. M. Olefsky (University of California, San Diego, Calif., USA) and were maintained in Dulbecco's modified Eagle's medium (DMEM) supplemented with 10\% fetal calf serum (FCS). Cells were cultured for 4-7 days and serum starved in the DMEM containing $0.05 \%$ FCS and $40 \mathrm{mmol} / \mathrm{l} \mathrm{HEPES}$, $\mathrm{pH} 7.4$ for $24 \mathrm{~h}$. After incubating the cells in the KRP-HEPES buffer with or without palmitate, cells were washed twice with phosphate buffered saline (PBS) and subjected to the following study.

Insulin binding study. Insulin binding to HIRc-B cells was measured as described previously [20] with some modifications. Briefly, confluent cells cultured in 24-well tissue culture plates were incubated with $0.1 \mathrm{ng} / \mathrm{ml}\left[{ }^{125} \mathrm{I}\right]$-insulin $(\sim 2000 \mathrm{Ci} / \mathrm{mmol})$ and unlabelled insulin at various concentrations in Minimum Essential Medium (MEM) containing $25 \mathrm{mmol} / \mathrm{l}$ HEPES and $1 \% \mathrm{BSA}$ at $\mathrm{pH} 7.4$ for $3 \mathrm{~h}$ at $15^{\circ} \mathrm{C}$. After removing free insulin by washing the cells three times with ice-cold PBS, the cells were lysed in $0.1 \mathrm{~N} \mathrm{NaOH}$ with $0.2 \%$ SDS and the radioactivity was counted in a gamma-counter. The values for non-specific insulin binding to the cells were determined by incubating cells with $400 \mathrm{nmol} / \mathrm{l}$ unlabelled insulin and were subtracted from each of the total values.

Immunoprecipitation and Western blotting. After incubation with various concentrations of insulin for the indicated times, cells were lysed in the cell solubilizing buffer containing $30 \mathrm{mmol} / \mathrm{l}$ Tris, $150 \mathrm{mmol} / \mathrm{l} \mathrm{NaCl}, 10 \mathrm{mmol} / \mathrm{l}$ EDTA, $0.5 \%$ sodium deoxycholate, $1 \%$ Nonidet-P40, 0.1\% SDS, $1 \mathrm{mmol} / 1$ phenylmethylsulphonyl fluoride (PMSF), $10 \mu \mathrm{g} / \mathrm{ml}$ aprotinin, $0.5 \mu \mathrm{g} / \mathrm{ml}$ leupeptin, $1 \mathrm{mmol} / 1 \mathrm{Na}_{3} \mathrm{VO}_{4}, 160 \mathrm{mmol} / \mathrm{l} \mathrm{NaF}, \mathrm{pH}$ 7.4 and incubated for $15 \mathrm{~min}$ at $4^{\circ} \mathrm{C}$ [17]. The cell lysate was centrifuged at $4^{\circ} \mathrm{C}$ for $10 \mathrm{~min}$ to remove the insoluble materials and the supernatant was boiled with Laemmli sample buffer [21] to analyse tyrosine-phosphorylated insulin receptor and insulin receptor substrate (IRS)-1. To determine the Shcphosphorylation, cell lysates were immunoprecipitated with anti-Shc antibody as described previously [17]. The cell lysates or immunoprecipitates were electrophoresed on $7.5 \%$ SDSPAGE and transferred onto polyvinylidene difluoride membrane (Amersham) in the Trans-Blot cell apparatus (Bio Rad) [16]. The membranes were immunoblotted with anti-phosphotyrosine antibody or anti-GLUT 1 antibody. The proteins were visualized with chemiluminescence reagents according to the manufacturer's protocol (Amersham).

Insulin stimulated tyrosine kinase activity of insulin receptor. Confluent cells in six well tissue culture plates were stimulated with $20 \mathrm{nmol} / \mathrm{l}$ insulin for $5 \mathrm{~min}$. Cells were lysed in $300 \mu \mathrm{l}$ of the cell solubilizing buffer and the cell lysate was centrifuged at $4{ }^{\circ} \mathrm{C}$ for $10 \mathrm{~min}$ to remove the insoluble materials. The supernatant was used for immunoprecipitation with $3 \mu l$ of anti-insulin receptor serum and $50 \mu \mathrm{l}$ of Protein A sepharose for $3 \mathrm{~h}$ at 
$4^{\circ} \mathrm{C}$. Tyrosine kinase reaction in the immunoprecipitates was

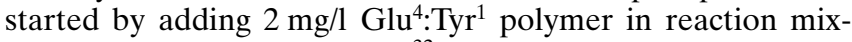
ture containing $50 \mu \mathrm{mol} / 1\left[\gamma_{-}{ }^{32} \mathrm{P}\right]$-ATP $(0.15 \mathrm{MBq} /$ tube $), 500$ $\mu \mathrm{mol} / \mathrm{l}$ cytidine $5^{\prime}$-triphosphate (CTP), $5 \mathrm{mmol} / \mathrm{l} \mathrm{MnCl}_{2}$, and

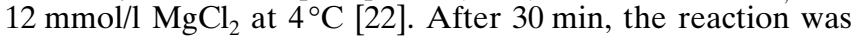
stopped by spotting the samples on Whatman 3MM papers. The papers were washed with $10 \%$ trichloroacetic acid five times and $50 \%$ ethanol once, then counted in a liquid scintillation counter.

Phosphatidylinositol (PI) 3-kinase assay. Confluent cells in $10 \mathrm{~cm}$ dishes were stimulated with various concentrations of insulin for $10 \mathrm{~min}$ and solubilized in a buffer containing (in mmol/1) 20 Tris, $100 \mathrm{NaCl}, 0.8 \mathrm{MgCl}_{2}, 0.8 \mathrm{CaCl}_{2}, 1 \mathrm{Na}_{3} \mathrm{VO}_{4}$, $1 \%$ Nonidet-P40, $10 \%$ glycerol, $1 \mathrm{mmol} / 1 \mathrm{PMSF}$ and $10 \mu \mathrm{g} / \mathrm{ml}$ aprotinin. The cell lysates were centrifuged at $10000 \times \mathrm{g}$ for $20 \mathrm{~min}$ at $4{ }^{\circ} \mathrm{C}$ to remove the insoluble materials. The supernatant was immunoprecipitated with anti-phosphotyrosine antibody for $2 \mathrm{~h}$, and then the immunocomplexes were collected by incubation with $50 \mu \mathrm{l}$ of $50 \%$ Protein A sepharose for $1 \mathrm{~h}$ at $4{ }^{\circ} \mathrm{C}$. The immunoprecipitates were washed twice with each of the following buffers: (i) PBS, containing $1 \%$ Nonidet-P40

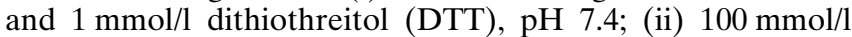
Tris/0.5 mol/1 LiCl/1 mmol/l DTT, pH 7.4; and (iii) $10 \mathrm{mmol} / \mathrm{l}$ Tris/100 mmol/1 NaCl/1 mmol/l DTT, $\mathrm{pH}$ 7.4. The phosphorylation reaction was started by adding $20 \mu \mathrm{l}$ of PI solution containing $0.5 \mathrm{mg} / \mathrm{ml} \mathrm{PI,} 50 \mathrm{mmol} / 1 \mathrm{HEPES}, 1 \mathrm{mmol} / 1 \mathrm{NaH}_{2} \mathrm{PO}_{4}$, $1 \mathrm{mmol} / \mathrm{l}$ EGTA at room temperature, followed by the addition of $10 \mu \mathrm{l}$ of the reaction mixture containing $250 \mu \mathrm{mol} / \mathrm{l}[\gamma$ $\left.{ }^{32} \mathrm{P}\right]$-ATP (0.37 MBq/tube), $100 \mathrm{mmol} / \mathrm{l} \mathrm{HEPES}$ and $50 \mathrm{mmol} / \mathrm{l}$ $\mathrm{MgCl}_{2}$ for $5 \mathrm{~min}$. The reaction was stopped by the addition of $15 \mu \mathrm{l}$ of $4 \mathrm{~mol} / \mathrm{l} \mathrm{HCl}$. The products were extracted by adding $130 \mu \mathrm{l}$ of chloroform/methanol (1:1) and centrifugation. The lower organic phase was removed and spotted on Silica Gel 60 plate. The plates were developed in $\mathrm{CHCl}_{3}: \mathrm{CH}_{3} \mathrm{OH}$ : $\mathrm{H}_{2} \mathrm{O}: \mathrm{NH}_{4} \mathrm{OH}$ (60:47:11.3:2) and dried. The phosphorylated inositol was visualized by autoradiography and phosphate incorporated into inositol was determined by the bio-image analyser (Fuji Film, Tokyo, Japan).

M itogen-activated protein ( M A P) kinase assay. Confluent cells in $10 \mathrm{~cm}$ dishes were incubated with $20 \mathrm{nmol} / \mathrm{l}$ insulin for $5 \mathrm{~min}$ and cells were lysed in lysis buffer containing (in $\mathrm{mmol} /$ 1) 10 Tris, $150 \mathrm{NaCl}, 2$ EGTA, 2 DTT, $1 \mathrm{Na}_{3} \mathrm{VO}_{4}, 160 \mathrm{NaF}, 1$ PMSF, $10 \mu \mathrm{g} / \mathrm{ml}$ leupeptin and $10 \mu \mathrm{g} / \mathrm{ml}$ aprotinin, and were then homogenized. The cell lysate was centrifuged at $25000 \times \mathrm{g}$ for $20 \mathrm{~min}$ and the supernatant was used for MAP kinase assay after adjusting the protein concentration. MAP kinase activity was measured using the p42/44 MAP kinase enzyme assay kit system (Amersham).

2-deoxyglucose (2-DOG) uptake. Cells were stimulated with various concentrations of insulin for $1 \mathrm{~h}$ in the KRP-HEPES buffer with $0.5 \% \mathrm{BSA}$ at $37^{\circ} \mathrm{C}$. When cells were treated with PD98059, cells were incubated with $50 \mu \mathrm{mol} / 1$ of PD98059 for $30 \mathrm{~min}$. Unlabelled $2-\mathrm{DOG}$ and $\left[{ }^{3} \mathrm{H}\right]-2-\mathrm{DOG}(0.1 \mathrm{mmol} / \mathrm{l}$, $0.74 \mathrm{kBq} /$ well $)$ were added to the cells and incubated for 5 min. Reaction was stopped by washing cells with ice-cold PBS three times. The cells were solubilized in $1 \mathrm{ml}$ of $1 \mathrm{~N}$ $\mathrm{NaOH}$ and neutralized with $1 \mathrm{ml}$ of $1 \mathrm{~N} \mathrm{HCl}$. The radioactivity was quantitated in a liquid scintillation counter as previously described [16].

M easurement of protein kinase $A$ (PKA) and CAMP. PKA : Confluent cells in 6-cm dishes were scraped into the PKA lysis buffer containing (in mmol/l) 50 Tris (pH 7.5), 5 EDTA, 10 EGTA, 50 2-mercaptoethanol, 10 benzamidine, 1 PMSF, $1 \mu \mathrm{g} /$

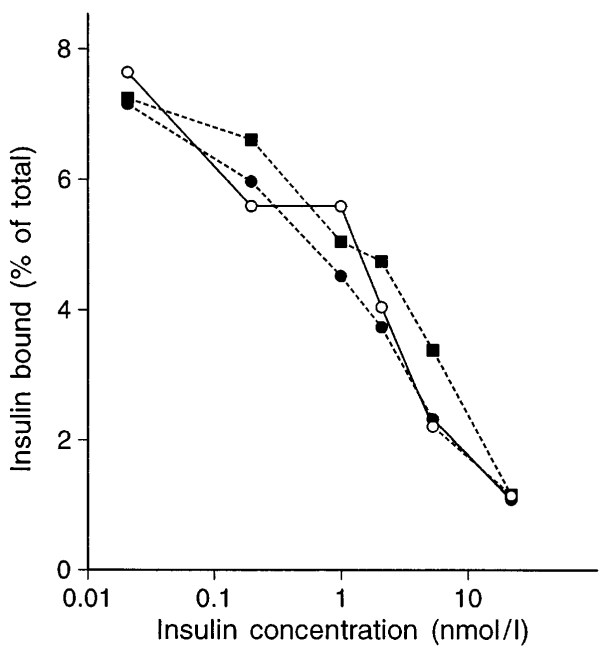

Fig. 1. Insulin binding to the cells. HIRc-B cells were incubated with $1 \mathrm{mmol} / \mathrm{l}$ palmitate for $1 \mathrm{~h}(----), 4 \mathrm{~h}\left(----^{--}\right)$or without palmitate $(-\bigcirc)$. After washing with PBS, insulin binding was measured as described in Methods. Results are shown as mean of three independent experiments

$\mathrm{ml}$ leupeptin and $25 \mu \mathrm{g} / \mathrm{ml}$ aprotinin and then homogenized. The cell lysates were centrifuged at $100000 \times \mathrm{g}$ for $60 \mathrm{~min}$ and the supernatants were used as the sample for the assay. Protein kinase activities were measured using a non-radioisotopic protein kinase assay kit (MESACUP Protein Kinase Assay Kit, MBL, Nagoya, Japan). PKA activity in intact cells was measured in the absence and presence of saturating exogenous cAMP and the intrinsic PKA activity was determined as the ratio of PKA activity in the absence of exogenous cAMP over the activity in the presence of cAMP. CA M P assay: Confluent cells in a 6-well tissue culture plate were serum-starved for $24 \mathrm{~h}$, then incubated in $2 \mathrm{ml}$ of KRP-HEPES buffer containing $100 \mu \mathrm{mol} / \mathrm{l}$ 3-isobutyl-1-methylxanthine (IBMX) with or without $1 \mathrm{mmol} / \mathrm{l}$ palmitate for $1 \mathrm{~h}$. The KRP-HEPES buffers with or without palmitate were directly used as extracellular samples for cAMP assay. The accumulation of cAMP in the medium was measured using cAMP enzyme-immunoassay system (Amersham).

Statistical analysis. All the data are presented as mean \pm SEM. The statistical comparison between groups were assessed using Student's t-test.

\section{Results}

Insulin binding study. The effect of NEFA on insulin binding to the cells was determined (Fig. 1). No significant difference in the insulin binding was found among cells treated with and without $1 \mathrm{mmol} / \mathrm{l}$ palmitate treatment for $1 \mathrm{~h}$ or $4 \mathrm{~h}$.

A utophosphorylation and tyrosine kinase activity of insulin receptor and phosphorylation of $52 \mathrm{kD}$ a Shc. Insulin stimulated tyrosine phosphorylation of insulin receptor $\beta$ subunit and $185 \mathrm{kDa}$ protein, which included both IRS-1 and IRS-2, within $5 \mathrm{~min}$. The pretreatment with palmitate for $1 \mathrm{~h}$ had no significant effect on both basal and insulin-stimulated tyrosine 

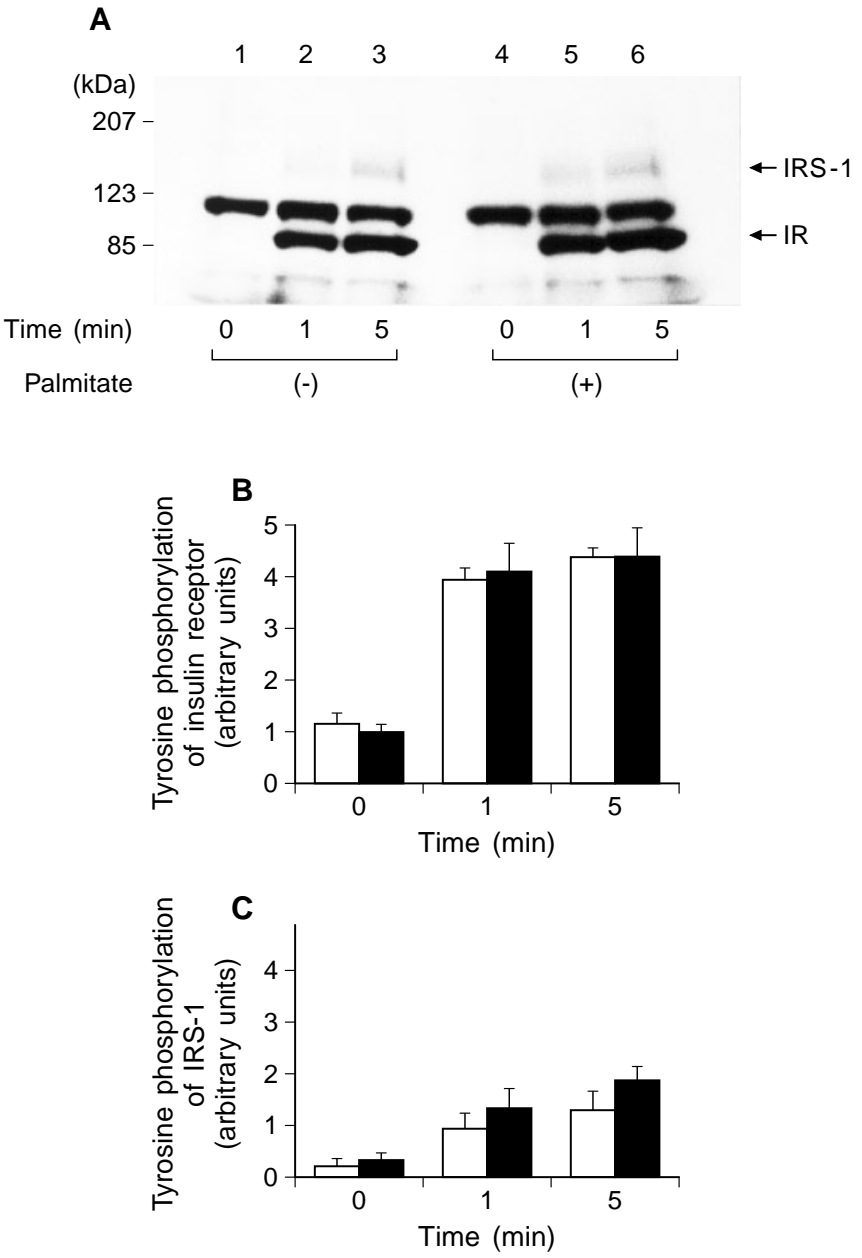

Fig. 2(A-C). Autophosphorylation of insulin receptor and insulin-stimulated phosphorylation of IRS-1. A. Autophosphorylation of insulin receptor and IRS-1 phosphorylation. After treatment without (lane 1-3) or with $1 \mathrm{mmol} / \mathrm{l}$ palmitate (lane 4-6) for $1 \mathrm{~h}$, HIRc-B cells were stimulated with $20 \mathrm{nmol} / \mathrm{l} \mathrm{insu-}$ lin for the indicated times. Cells were solubilized and analysed by SDS-PAGE and immunoblotting with PY20. B, C. Effect of palmitate on phosphorylation of Insulin Receptor (B) and IRS-1 (C). The signal intensity of insulin receptor and IRS-1 in control $(\square)$ and palmitate-treated cells $(\square)$ was quantitated by densitometry. Results are shown as mean \pm SEM of three independent experiments

phosphorylation of these two proteins (Fig. 2A-C). Insulin stimulated $52 \mathrm{kDa}$ Shc tyrosyl phosphorylation by 4.2-fold over basal (Fig. 3A). Basal and insulin-stimulated Shc phosphorylation in the palmitatetreated cells was comparable to that in the control (Fig. 3B). Tyrosine kinase activity toward Glu Tyr $^{1}$ polymer as an exogenous substrate was also determined. There was no significant difference between the palmitate-treated and untreated groups in both basal and insulin-stimulated state (Fig.3C). The tyrosine kinase activity of the partially purified insulin receptors from cells with or without palmitate treatment showed similar results (data not shown). Therefore, there were no direct effects of palmitate
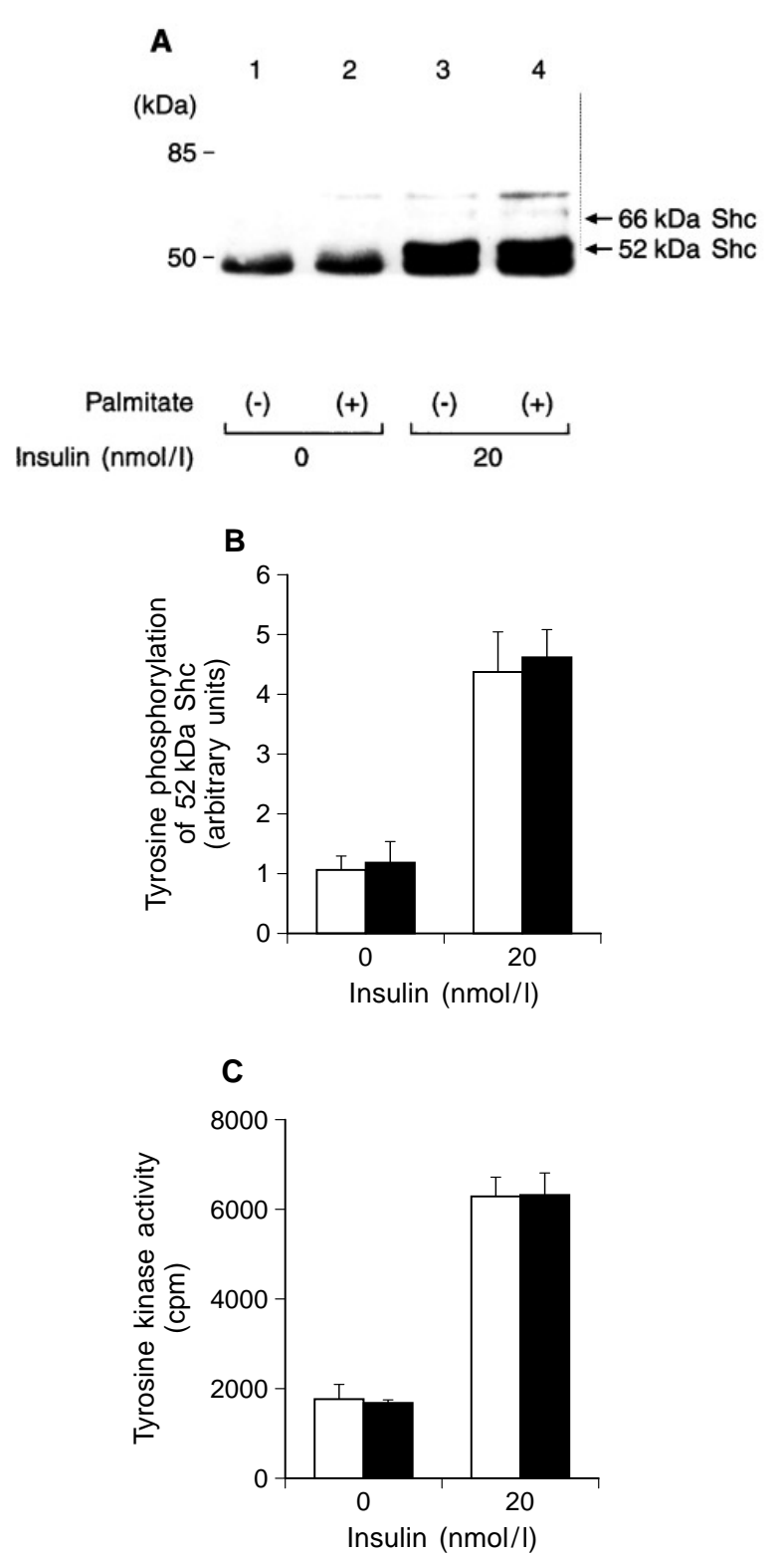

Fig. 3(A-C). Effect of palmitate on Shc phosphorylation and insulin receptor tyrosine kinase activity. A. Shc phosphorylation.After treatment without (lane 1,3 ) or with $1 \mathrm{mmol} / \mathrm{l}$ palmitate (lane 2, 4) for $1 \mathrm{~h}$, HIRc-B cells were stimulated with 20 $\mathrm{nmol} / \mathrm{l}$ insulin for $5 \mathrm{~min}$, and cell lysates were immunoprecipitated with anti-Shc antibodies. The immunoprecipitates were analysed by SDS-PAGE and immunoblotting with PY20. B. Effect of palmitate on Shc phosphorylation. The signal intensity in control $(\square)$ and palmitate-treated cells ( $\square$ ) were quantitated by densitometry. Results are shown as mean \pm SEM of four independent experiments. C. Insulin receptor tyrosine kinase activity. After palmitate treatment, cells were incubated with insulin $(20 \mathrm{nmol} / \mathrm{l})$ for $5 \mathrm{~min}$ at $37^{\circ} \mathrm{C}$, followed by solubilization and immunoprecipitation with anti-insulin receptor antibody. Tyrosine kinase activities in the immunoprecipitated insulin receptors from control cells $(\square)$ and $1 \mathrm{~h}$ palmitate treated cells $(\square)$ are shown as mean \pm SEM of three independent experiments 

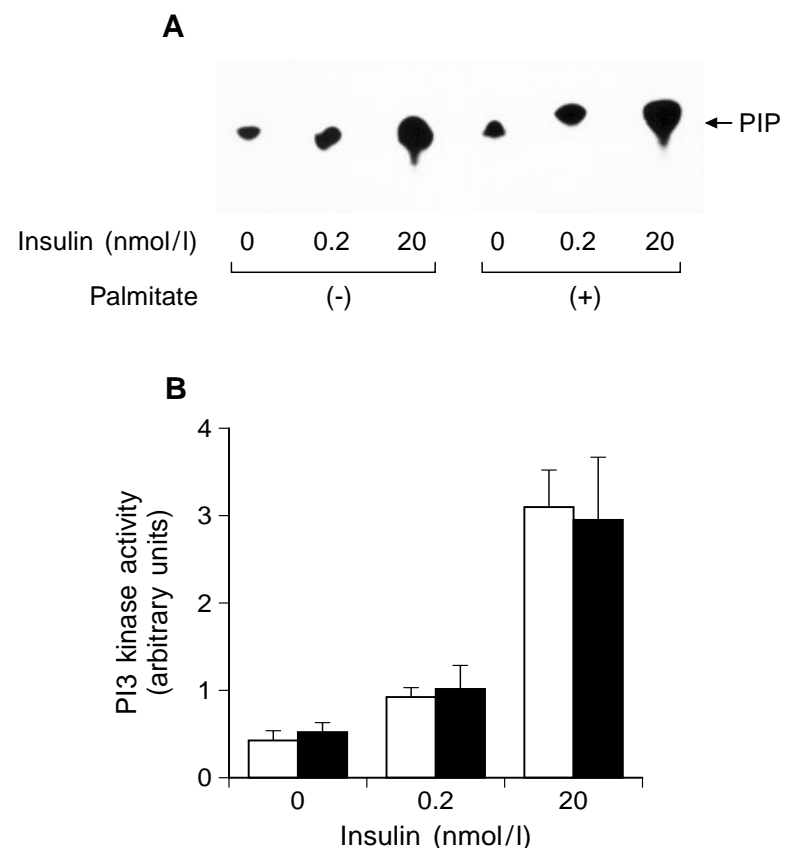

Fig. 4(A , B ). Effect of palmitate on PI3-kinase activity. After treatment with $1 \mathrm{mmol} / \mathrm{l}$ palmitate for $1 \mathrm{~h}(\square)$ or with buffer $(\square)$ for $1 \mathrm{~h}$, HIRc-B cells were treated with indicated concentration of insulin for $10 \mathrm{~min}$. The PI3-kinase activity in the immunoprecipitate with anti-phosphotyrosine antibody was measured. A representative autoradiogram of the thin-layer chromatography is shown in (A). The arrow indicates the migration of non-labelled PtdIns(4)P as a standard. The labelled lipid products on the autoradiograms were quantitated by bio-image analyser (B). Results are shown as mean \pm SEM of three independent experiments

treatment on insulin receptor tyrosine kinase activity in HIRc-B cells.

PI3-kinase activity. Insulin stimulated PI3 kinase in a dose-dependent manner and the activity reached the maximum at $20 \mathrm{nmol} / \mathrm{l}$ insulin in control cells. The basal and the insulin stimulated PI3 kinase activity in palmitate treated cells was comparable to that in control cells (Fig.4).

M AP kinase activity. Insulin significantly stimulated MAP kinase activity in the control cells, while insulin-stimulated MAP kinase activity in the cell lysates was almost completely inhibited by palmitate treatment (Fig. 5). Epidermal growth factor (EGF) stimulated MAP kinase activity in these cells, and palmitate treatment also inhibited its stimulation. Palmitate treatment did not change the basal MAP kinase activity and therefore, palmitate specifically inhibited both insulin and EGF stimulated MAP kinase activity in HIRc-B cells.

2-deoxyglucose (2-DOG) uptake. Insulin maximally increased 2-DOG uptake to threefold that of the basal in the control cells. Preincubation with $1 \mathrm{mmol} / \mathrm{l}$

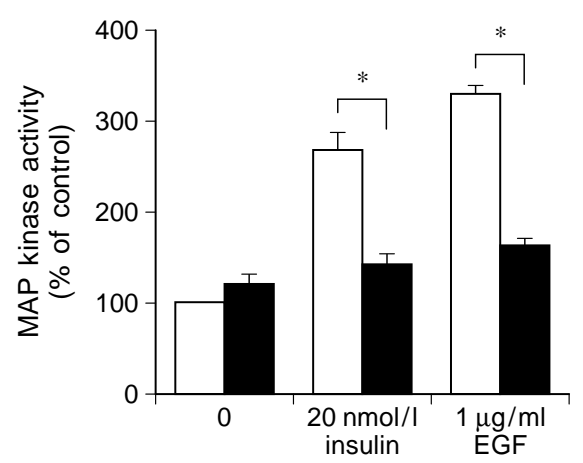

Fig. 5. Effect of palmitate on MAP kinase activity. After treatment with $1 \mathrm{mmol} / \mathrm{l}$ palmitate $(\square)$ or with buffer $(\square)$ for $1 \mathrm{~h}$, HIRc-B cells were stimulated with $20 \mathrm{nmol} / \mathrm{l}$ insulin or $1 \mu \mathrm{g} /$ $\mathrm{ml}$ EGF for $5 \mathrm{~min}$. MAP kinase activity in the cell lysates was measured as described in Methods. The results are shown as percent of control and mean \pm SEM of three independent experiments. Actual counts were $1589 \pm 243,1895 \pm 67 \mathrm{cpm}$ in the basal, $4312 \pm 1195,2263 \pm 614 \mathrm{cpm}$ in the presence of insulin $(20 \mathrm{nmol} / \mathrm{l})$ and $5309 \pm 132,2627 \pm 97.8 \mathrm{cpm} / 150 \mu \mathrm{g}$ protein in the presence of EGF $(1 \mu \mathrm{g} / \mathrm{ml})$ for control and palmitatetreated cells, respectively. $* p<0.005$ vs control group

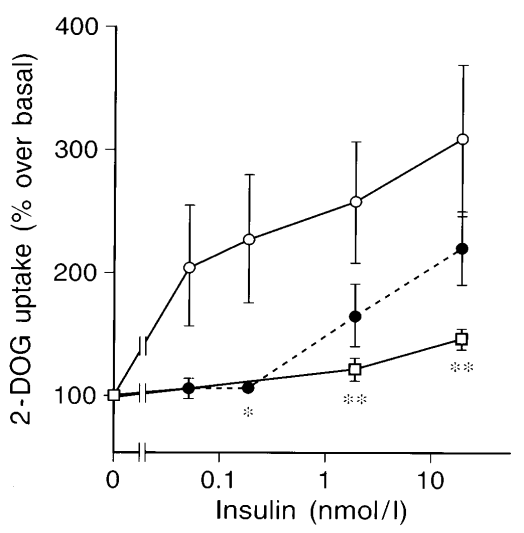

Fig. 6. Effect of palmitate and MAP kinase inhibiter on 2DOG uptake. After stimulation with the indicated concentration of insulin, 2-DOG uptake into control (- $-(-)$, palmitate-treated (-- -) and PD98059-treated $(-\square-)$ cells were measured as described in Methods. The results from four independent experiments are shown as percent over basal (mean \pm SEM). Basal and maximal 2-DOG incorporation (B/M) into the cells were $0.71 / 1.64,0.97 / 2.03$ and $0.71 / 1.03$ $\mathrm{nmol} \cdot \mathrm{mg}$ protein ${ }^{-1} \cdot 5 \mathrm{~min}^{-1}$ in control, palmitate-treated and PD98059-treated cells, respectively. $* p<0.05, * * p<0.005$ vs control group

palmitate caused a rightward shift of the insulin-dose responsive curve in 2-DOG uptake. $\mathrm{ED}_{50}$ of the insulin dose response curve was 0.1 and $1 \mathrm{nmol} / \mathrm{l}$ insulin for control and palmitate-treated cells, respectively (Fig. 6). When insulin-stimulated MAP kinase activity was completely inhibited by the treatment with PD98059, a specific MEK inhibiter, insulin-stimulated 2DOG uptake was severely inhibited (Fig.6). Palmitate treatment for $1 \mathrm{~h}$ did not cause an acute degradation of glucose transporter 1 (GLUT 1), which 
A

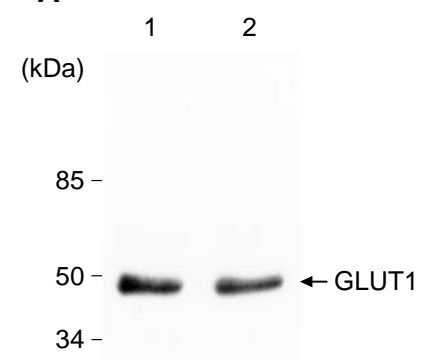

Palmitate

$(-)$

$(+)$

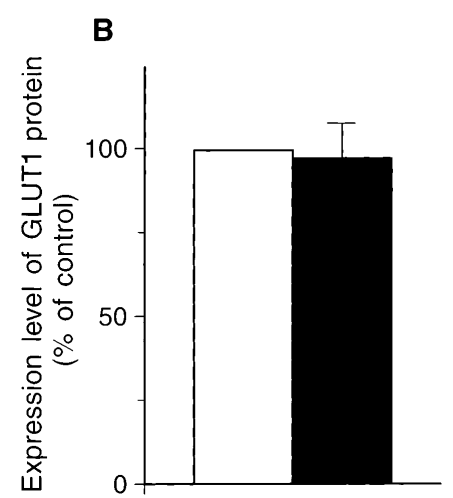

Fig. 7(A, B ). Expression level of GLUT 1 protein. A. After treatment with $1 \mathrm{mmol} / \mathrm{l}$ palmitate (lane 2) or with buffer (lane 1 ) for $1 \mathrm{~h}$, cells were solubilized and analysed by SDSPAGE and immunoblotting with anti-GLUT 1 antibody. This experiment was conducted three times and the representative film is shown. B. Effect of palmitate on expression level of GLUT 1 protein. The signal intensity of GLUT 1 in control $(\square)$ and palmitate-treated cells $(\square)$ was quantitated by densitometry. Results are shown as mean \pm SEM of three independent experiments

Table 1. Effect of palmitate on the activity of protein kinase A and cAMP levels

\begin{tabular}{lll}
\hline & $\begin{array}{l}\text { PKA } \\
(-c A M P /+\mathrm{cAMP})\end{array}$ & $\begin{array}{l}\text { cAMP } \\
\left(\mathrm{fmol} / 10^{6} \text { cells }\right)\end{array}$ \\
\hline Control & $0.15 \pm 0.07$ & $2319.6 \pm 794.1$ \\
Palmitate $(1 \mathrm{mmol} / \mathrm{l})$ & $0.13 \pm 0.04$ & $2634.3 \pm 265.9$ \\
\hline
\end{tabular}

a The ratio of PKA activity in the absence of cAMP over the activity in the presence of cAMP is presented. Results are shown as mean \pm SEM of three independent experiments

is a major glucose transporter and therefore abundant in the plasma membrane even at basal level in fibroblasts and myoblasts (Fig. 7) [13].

Protein kinase $A$ (PKA) activity and CAMP. Increased PKA activity is generally associated with decreased MAP kinase activity [23]. To examine the possible role of PKA for the inhibited insulin-stimulated MAP kinase activity in the palmitate treated cells, we measured the activity of PKA and cyclic AMP level following the incubation with $1 \mathrm{mmol} / \mathrm{l}$ palmitate for $1 \mathrm{~h}$. Forskolin treatment significantly increased PKA activity and cAMP level (data not shown), suggesting that the Rat-1 cells had PKA signalling pathways. Both PKA activity and cAMP levels were comparable in control and palmitate-treated cells as shown in Table 1.

\section{Discussion}

Thus far, the direct effects of NEFA on insulin signal transduction have not been well-characterized. Our results showed that palmitate, a major component of saturated NEFA, changed neither insulin binding nor insulin receptor tyrosine kinase activity. These results are different from those in cultured hepatoma cells, 3T3-L1 cells and liver or muscle cells from high fat-fed rats $[8,11]$, but are similar to the recent report by Hunnicutt et al. [9]. They concluded that the different results were due to the effect of free radicals produced by the unsaturated acids and the effect of Tris buffer which would inhibit insulin receptor recycling. The length of NEFA treatment time might be an explanation because we treated the cells for a relatively short time. However, even when retinoblastoma cells were incubated with palmitate for a $24 \mathrm{~h}$, neither the composition of the membrane nor insulin binding was affected [12]. In animal models, we have reported that insulin binding and insulin receptor tyrosine kinase activity in both rat muscles and liver cells are decreased by high fat feeding which causes elevated serum NEFA levels [22, 24]. In these studies, however, high fat feeding induced hyperlipidaemia together with hyperinsulinaemia, which alone could cause the down-regulation of insulin receptors and the decreased insulin receptor tyrosine kinase activity [25]. Therefore, an in vitro cell culture system is necessary to clarify the mechanism of NEFA-induced insulin resistance.

The recent studies revealed the two distinct insulin signalling pathways. One pathway mediates metabolic effects through IRS-1 and PI3 kinase and the other mediates mitogenic action through Shc-ras-MAP kinase [26]. PI3 kinase is considered to be important for both GLUT 1 and GLUT 4 translocation and one would expect the impairment of this kinase caused insulin resistance [27]. Unexpectedly, palmitate did not affect either basal or insulin stimulated phosphorylation of $185 \mathrm{kDa}$ protein, which is presumably IRS-1 or IRS-2 [17, 28], and PI3-kinase activity. Palmitate treatment did not change either basal or insulin-stimulated IRS-1 phosphorylation in L6 cells (data not shown), suggesting this finding was not unique in the transfected Rat-1 fibroblasts. Therefore, the cause for the impairment of insulin stimulated glucose uptake in the palmitate treated cells resided in the 
downstream of the IRS-1-PI3-kinase signalling pathway or another unknown pathway.

Contrary to the normal PI3-kinase activity, palmitate treatment severely impaired insulin-stimulated MAP kinase activity. GLUT 1 is the major glucose transporter in these fibroblast cells and is also regulated by MAP kinase [15, 29]. Both palmitate and PD98059 treatment impaired insulin-stimulated 2DOG uptake together with MAP kinase activity. Thus, inhibited MAP kinase is a likely cause for the rightward shift in the insulin dose response curve of glucose uptake in these cells.

Recently, Roden et al. [30] reported that NEFA induced insulin resistance in humans by inhibition of glucose transport/phosphorylation. They measured whole body glucose uptake by using ${ }^{13} \mathrm{C}$ and ${ }^{31} \mathrm{P}$ nuclear magnetic resonance spectroscopy in the presence of low and high plasma NEFA levels. In contrast to the originally postulated mechanism, i.e. elevation of intramitochondrial acetyl $\mathrm{CoA} / \mathrm{CoA}$ and NADH/ $\mathrm{NAD}^{+}$ratios with subsequent inactivation of pyruvate dehydrogenase, phosphofructokinase and hexokinase [31], they claim that NEFA primarily inhibits glucose transport/phosphorylation, and that decreased transport activity may be accounted for by decreased amount of GLUT 4 or reduced intrinsic activty of GLUT 4. In our experiment, the decreased glucose uptake activity in response to insulin stimulation may be due to either diminished GLUT 1 expression, its translocation or intrinsic activity. However, total levels of GLUT 1 protein were not affected by $1 \mathrm{~h}$ treatment with palmitate in these cells [Fig.7]. Therefore, decreased MAP kinase by NEFA may be the cause of decreased glucose uptake, probably due to diminished GLUT 1 translocation and/or intrinsic activity. Further study is necessary to evaluate the effect of palmitate on GLUT 4 translocation and MAP kinase activity in adipocyte and muscle cell lines.

As insulin-stimulated Shc phosphorylation leads to the activation of ras-raf-1-MAP kinase cascade, our data suggest that palmitate may interfere with the pathway between Shc and MAP kinase. Since immunoblotting with anti-MAP kinase antibody showed comparable expression level of MAP kinase protein both in control and palmitate treated cells (data not shown), the impaired MAP kinase activity was due to its functional abnormality. The activity of MAP kinase was known to be regulated by raf-1 whose activity was suppressed by PKA activation $[32,33]$. Catecholamines, well-known PKA activators, are also known to cause insulin resistance [34, 35]. However, both PKA activity and cAMP levels in the palmitate-treated cells were normal. Although palmitate acts in a similar way to catecholamines, which induce increased basal but inhibited insulinstimulated glucose uptake in the adipocytes, the activated PKA is not the mechanism for NEFA-induced insulin resistance.
Similar phenomena, i.e. normal MAP kinase activity at the basal and the decreased insulin-stimulated MAP kinase activity, were demonstrated in the streptozotocin-induced diabetic rats and were restored by treatment with vanadate [36]. Since NEFA were also increased in these diabetic rats, the cause of the decreased MAP kinase activity might be hyperglycaemia and co-existant increased serum NEFA levels. Vanadate treatment improved the MAP kinase activity in the diabetic rats, probably through inactivating dual Tyr/Thr phosphatase which inhibited MAP kinase activity [37]. Therefore, palmitate might activate dual phosphatases of MAP kinase, such as MAP kinase phosphatase 1 or 2 , leading to inhibition of insulin-stimulated phosphorylation and activation of MAP kinase [38]. The present studies do not rule out the possibility that palmitate may inhibit other unknown insulin signal transduction pathways. Interestingly, tumour necrosis factor (TNF)- $\alpha$, which causes insulin resistance in obese animals, inhibited insulin-induced activation of MAP kinase by stimulating protein serine/threonine phosphatase 2 activity in L6 rat skeletal muscle cells [39].

In summary, we described an inhibitory effect of palmitate on insulin-stimulated glucose uptake without any change in the early step of insulin signal transduction including insulin receptor tyrosine kinase, IRS-1 phosphorylation, PI3 kinase activity and Shc phosphorylation. However, palmitate impaired insulin-stimulated MAP kinase. These results suggest that the mechanism of saturated NEFA induced insulin resistance in glucose uptake may reside at post IRS-1 or Shc step, including the level of MAP kinase activation.

A cknowledgements. This study was supported in part by a Grant-in-Aid for Scientific Research from the Ministry of Education, Science and Culture, Japan, and a grant from ONO Medical Research Foundation a grant from Otsuka Pharmaceutical Co. Ltd, Japan.

\section{References}

1. Boden G, Chen X (1995) Effects of fat on glucose uptake and utilization in patients with non-insulin-dependent diabetes. J Clin Invest 96: 1261-1268

2. Lee KU, Lee HK, Koh CS, Min HK (1988) Artificial induction of intravascular lipolysis by lipid-heparin infusion leads to insulin resistance in man. Diabetologia 31: 285-290

3. Boden G, Jadali F, White J et al. (1991) Effects of fat on insulin-stimulated carbohydrate metabolism in normal men. J Clin Invest 88: 960-966

4. Saad MJA, Araki E, Miralpeix M, Rothenberg PL, White MF, Kahn CR (1992) Regulation of insulin receptor substrate- 1 in liver and muscle of animal models of insulin resistance. J Clin Invest 90: 1839-1849

5. Saha AK, Kurowski TG, Colca JR, Ruderman NB (1994) Lipid abnormalities in tissues of the KKA ${ }^{y}$ mouse - effects of pioglitazone on malonyl-CoA and diacylglycerol. Am J Physiol 267:E95-E101 
6. King PA, Horton ED, Hirshman MF, Horton ES (1992) Insulin resistance in obese Zucker rat (fa/fa) skeletal muscle is associated with a failure of glucose transporter translocation. J Clin Invest 90: 1568-1575

7. Kobayashi M, Iwanishi M, Egawa K, Shigeta Y (1992) Pioglitazone increases insulin sensitivity by activating insulin receptor kinase. Diabetes 41: 476-483

8. Grunfeld C, Baird KL, Kahn CR (1981) Maintenance of 3T3-L1 cells in culture media containing saturated fatty acids decreases insulin binding and insulin action. Biochem Biophys Res Commun 103: 219-226

9. Hunnicutt JW, Hardy RW, Williford J, McDonald JM (1994) Saturated fatty acid-induced insulin resistance in rat adipocytes. Diabetes 43: 540-545

10. Svedberg J, Björntorp P, Smith U, Lönnroth P (1990) Freefatty acid inhibition of insulin binding, degradation, and action in isolated rat hepatocytes. Diabetes 39: 570-574

11. Hubert P, Bruneau-Wack C, Cremel G, Marchand-Brustel LY, Staedel C (1991) Lipid-induced insulin resistance in cultured hepatoma cells is associated with a decreased insulin receptor tyrosine kinase activity. Cell Regulation 2: 6572

12. Yorek M, Leeney E, Dunlap J, Ginsberg B (1989) Effect of fatty acid composition on insulin and IGF-I binding in retinoblastoma cells. Invest Ophthalmol Vis Sci 30: 2087-2092

13. Kaliman P, Vinals F, Testar X, Palacin M, Zorzano A (1995) Disruption of GLUT 1 glucose carrier trafficking in L6E9 and Sol8 myoblasts by the phosphatidylinositol 3-kinase inhibitor wortmannin. Biochem J 312: 471-477

14. Skolnik EY, Lee CH, Batzer AG et al. (1993) The SH2/ SH3 domain containing protein GRB2 interacts with tyrosine phosphorylated IRS-I and Shc: implications for insulin control of ras signaling. EMBO J 12: 1929-1936

15. Fingar DC, Birnbaum MJ (1994) A role for Raf-1 in the divergent signaling pathways mediating insulin-stimulated glucose transport. J Biol Chem 269: 10127-10132

16. Takata Y, Webster NJG, Olefsky JM (1992) Intracellular signaling by a mutant human insulin receptor lacking the carboxyl-terminal tyrosine autophosphorylation sites. J Biol Chem 267: 9065-9070

17. Sasaoka T, Drazin B, Leitner JW, Langlois WJ, Olefsky JM (1994) Shc is the predominant signaling molecule coupling insulin receptors to activation of guanine nucleotide releasing factor and p $21^{\text {ras }}$ GTP formation. J Biol Chem 269: 10734-10738

18. Vessby B, Aro A, Skarfors E, Berglund L, Salminen I, Lithell H (1994) The risk to develop NIDDM is related to the fatty acid composition of the serum cholesterol esters. Diabetes 43: 1353-1357

19. Spector AA, Hoak JC (1969) An improved method for the addition of long-chain free fatty acid to protein solutions. Anal Biochem 32: 297-302

20. Sasaoka T, Kobayashi M, Takata Y et al. (1988) Clarification of signaling pathways mediated by insulin and insulinlike growth factor I receptors in fibroblasts from patients with specific defect in insulin receptor. Diabetes 37: 15151523

21. Laemmli UK (1970) Cleavage of structural proteins during the assembly of the head of bacteriophage T4. Nature 227: 680-685

22. Watarai T, Kobayashi M, Takata Y, Sasaoka T, Iwasaki M, Shigeta Y (1988) Alteration of insulin-receptor kinase activity by high-fat feeding. Diabetes 37: 1397-1404

23. VanRenteghen B, Browning MD, Maller JL (1994) Regulation of mitogen-activated protein kinase activation by protein kinases $\mathrm{A}$ and $\mathrm{C}$ in a cell-free system. J Biol Chem 269: 24666-24672
24. Iwanishi M, Kobayashi M (1993) Effect of pioglitazone on insulin receptors of skeletal muscles from high-fat-fed rats. Metabolism 42: 1017-1021

25. Garvey WT, Olefsky JM, Marshall S (1986) Insulin induces progressive insulin resistance in cultured rat adipocytes sequential effects at receptor and multiple postreceptor sites. Diabetes 35: 258-267

26. Cheatham B, Kahn CR (1995) Insulin action and insulin signaling network. Endocrine Reviews 16: 117-142

27. Clarke JF, Young PW, Yonezawa K, Kasuga M, Holman GD (1994) Inhibition of the translocation of GLUT1 and GLUT4 in 3T3-L1 cells by the phosphatidylinositol 3-kinase inhibitor, wortmannin. Biochem J 300: 631-635

28. Rose DW, Saltiel AR, Majumdar M, Decker SJ, Olefski JM (1994) Insulin receptor substrate 1 is required for insulinmediated mitogenic signal transduction. Proc Natl Acad Sci 91: 797-801

29. Merrall NW, Plevin RJ, Stokoe D, Cohen P, Nebreda AR, Gould GW (1993) Mitogen-activated protein kinase (MAP kinase), MAP kinase kinase and c-MOS stimulate glucose transport in Xenopus oocytes. Biochem J 295: 351-355

30. Roden M, Price TB, Perseghin G et al. (1996) Mechanism of free fatty acid-induced insulin resistance in humans. J Clin Invest 97: 2859-2865

31. Randle PJ, Garland PB, Hales CN, Newsholme EA (1963) The glucose fatty-acid cycle - its role in insulin sensitivity and the metabolic disturbances of diabetes mellitus. Lancet I:785-789

32. Graves LM, Bornfeldt KE, Raines EW et al. (1993) Protein kinase A antagonizes platelet-derived growth factor-induced signaling by mitogen-activated protein kinase in human arterial smooth muscle cells. Proc Natl Acad Sci USA 90: 10300-10304

33. Wu J, Dent P, Jelinek T, Wolfman A, Weber MJ, Sturgill TW (1993) Inhibition of the EGF-activated MAP kinase signaling pathway by adenosine 3 ',5'-monophosphate. Science 262: 1065-1069

34. Häring H, Kirsch D, Obermaier B, Ermel B, Machicao F (1986) Decreased tyrosine kinase activity of insulin receptor isolated from rat adipocytes rendered insulin-resistant by catecholamine treatment in vitro. Biochem J 234: 59-66

35. Kirsch DM, Baumgarten M, Deufel T, Rinninger F, Kemmler W, Häring HU (1983) Catecholamine-induced insulin resistance of glucose transport in isolated rat adipocytes. Biochem J 216: 737-745

36. Hei Yj, Chen X, Pelech SL, Diamond J, McNeill JH (1995) Skeletal muscle mitogen-activated protein kinases and ribosomal S6 kinases - suppression in chronic diabetic rats and reversal by vanadium. Diabetes 44: 1147-1155

37. Montgomery RB, Moscatello DK, Wong AJ, Cooper JA, Stahl WL (1995) Differential modulation of mitogen-activated protein (MAP) kinase/extracellular signal-related kinase kinase and MAP kinase activities by a mutant epidermal growth factor receptor. J Biol Chem 270: 3056230566

38. Chu Y, Solski PA, Khosravi-Far R, Der CJ, Kelly K (1996) The mitogen-activated protein kinase phosphatase PAC1, MKP-1 and MKP-2 have unique substrate specificities and reduced activity in vivo toward the ERK2 sevenmaker mutation. J Biol Chem 271: 6497-6501

39. Begum N, Ragolia L, Srinivasan M (1996) Effect of tumor necrosis factor- $\alpha$ on insulin-stimulated mitogen-activated protein kinase cascade in cultured rat skeletal muscle cells. Eur J Biochem 238: 214-220 